\title{
ÚJABB KUTATÁS A KAPOSSZENTJAKABI APÁTSÁG TEMPLOMÁNAK TERÜLETÉN
}

\author{
MOLNÁR ISTVÁN*
}

\begin{abstract}
The Benedictine abbey of Kaposszentjakab (Zselicszentjakab) was founded in 1061. Its remains were excavated by Emese Nagy in 1960-1966. Although the reconstruction of the abbey church has since long intrigued research, it is still uncertain whether the earliest abbey church had an axial or a central structure. The new excavations in 2013-2014 unearthed sections of the foundations of a church built prior to the abbey's foundation. The remains of this early church were incorporated into the new building. The church was rebuilt during the Gothic period, when it received a vaulting.
\end{abstract}

Keywords: Middle Ages, Benedictine abbey, cemetery

Az 1061-ben alapitott kaposszentjakabi (zselicszentjakabi) bencés monostor maradványait 19601966 között tárták fel Nagy Emese vezetésével. A különleges szerkezetü apátsági templom eredeti formájának rekonstruálása régóta foglalkoztatja a kutatást. A 2013-2014-ben folytatott újabb ásatások során azonosítottuk az apátság alapítása előtt a területen álló templom alapozásának megmaradt szakaszait. Az új templom épitése során hasznositották a régi egyház falait. A monostortemplomot később gótikus stílusban átépitették, boltozták.

Kulcsszavak: középkor, bencés apátság, temető

\section{A monostor temploma}

Az apátság Kaposvár határában, az erdős Zselicség és a Kapos-völgy találkozásánál épült (1-2. kép). Alapításának körülményeit az alapítólevél 1432. évi átiratából ismerjük. ${ }^{1} \mathrm{E}$ szerint Győr nembeli Atha (Ottó) nádor és somogyi ispán a Szent Jakab hegyének nevezett magaslaton alapította monostorát, ahol már volt egy, az említett szent tiszteletére szentelt templom, amely „szerfölött régisége és elhanyagoltsága

\footnotetext{
A kézirat érkezett: 2015. március 1.

* Molnár István. Rippl-Rónai Megyei Hatókörü Városi Múzeum 7400 Kaposvár, Fó út 10.; molnaristvan74@yahoo.com

1 KumOROVITZ 1964.
}

miatt már pusztán állt". A domb lakott volt, de az itt élőket az alapító elköltöztette. Az alapítás után néhány év alatt felépült a kolostor temploma, amelyet - a Képes Krónika adata szerint a dalmáciai hadjáratról hazatérő Salamon király és Géza herceg jelenlétében, 1067-ben szenteltek fel. ${ }^{2}$

Az apátság jelentős birtokokkal rendelkezett. 1392-ben búcsúengedélyt kapott. Az 1508-as bencés vizitáció idején az apáttal együtt hat szerzetes élt az akkor még jó állapotban lévő épületegyüttesben. 1543-ban a szerzetesek elhagyták a monostort. Katonák érkeztek a helyükre, majd Kaposvárral együtt török kézre került. A vissza-

2 Képes Krónika 99. 


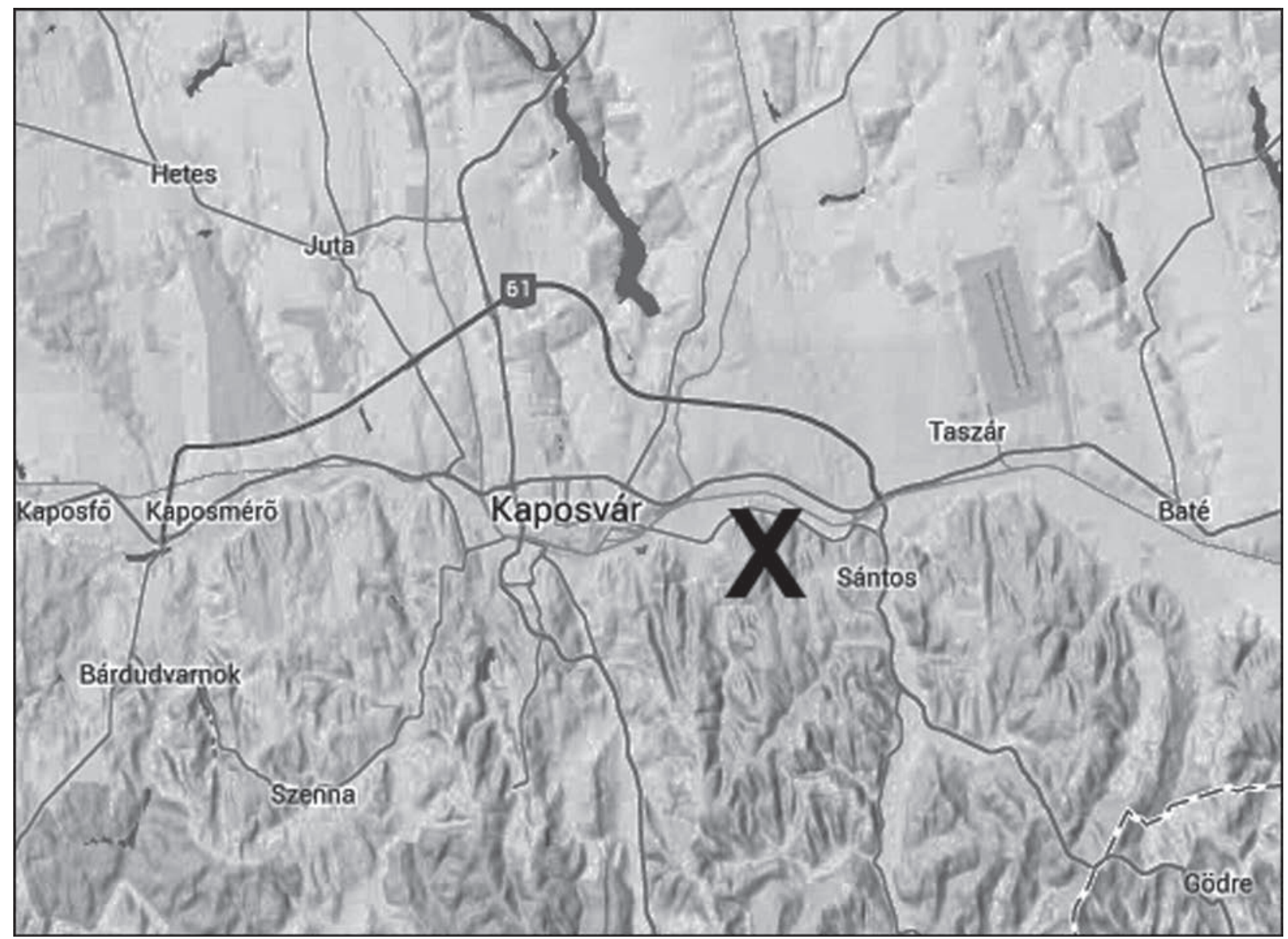

1. kép. Kaposszentjakab. A lelőhely elhelyezkedése

Fig. 1. Kaposszentjakab. Location of the site

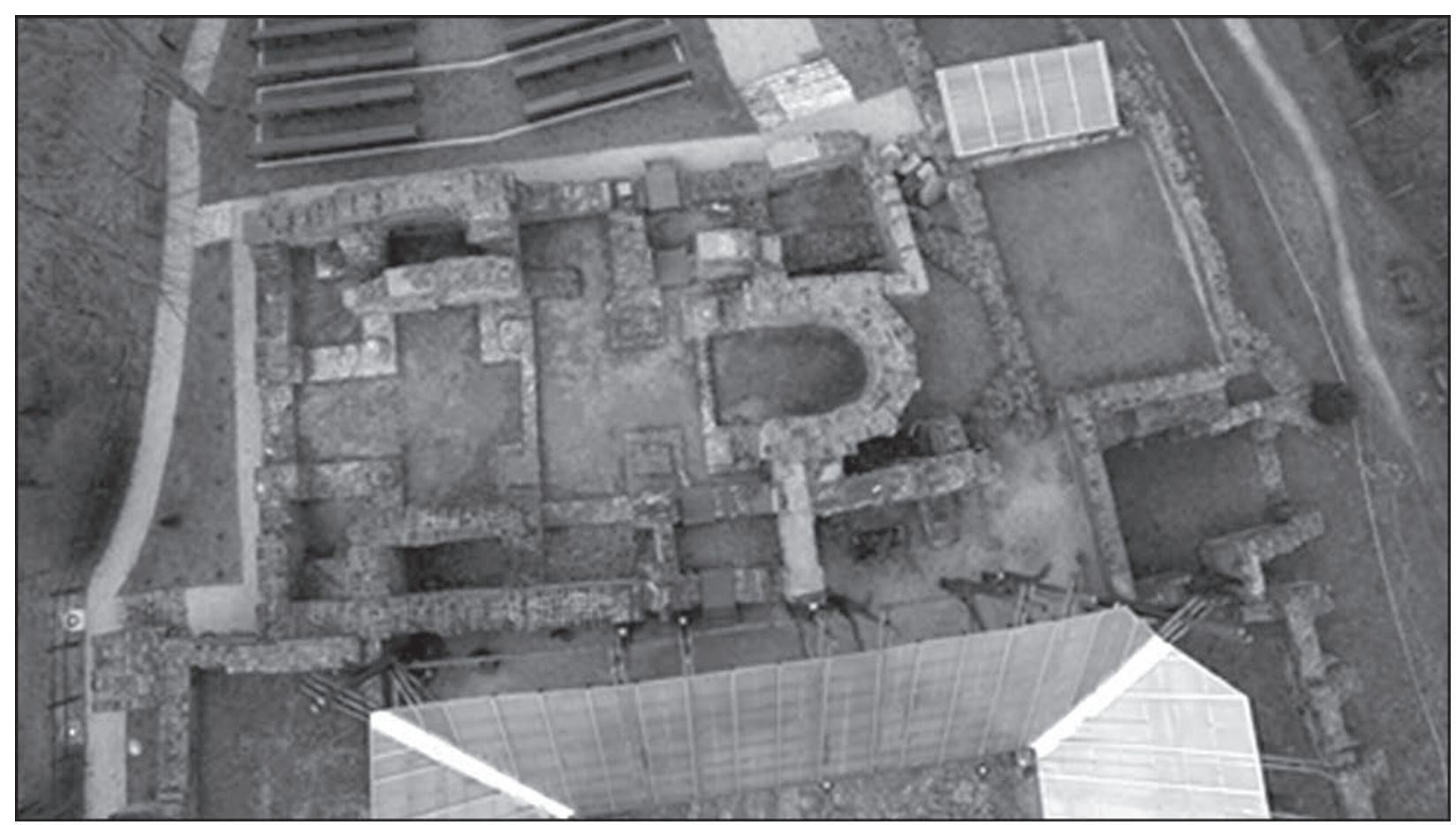

2. kép. Kaposszentjakab. Légi felvétel az apátság templomáról (Pazirik Kft. felvétele)

Fig. 2. Kaposszentjakab. Aerial photo of the abbey's church (photo by Pazirik Kft.) 
foglaló háborúk után már nem települt újjá, maradványait részint elhordták, részint föld alá kerültek. ${ }^{3}$

Az első, Nagy Emese által irányított feltárások 1960-1966 között napvilágra hozták a helyenként több méter magasan megmaradt falakat, számos sírt és értékes kőfaragvány-töredéket. Tisztázták a templom és a kolostori épületek alaprajzát és időrendjét. Az alapozásnak azonban csupán egyes részleteit dokumentálták. ${ }^{4}$ A Zádor Mihály által vezetett múemléki helyreállítás a feltárással együtt folyt.

Nagy Emese 1973-ban megjelent rövid ásatási beszámolójában megállapította, hogy a most romjaiban látható templom az alapítás után épült, így a legrégebbi része a monostornak. Félköríves apszissal záródó főhajóról és keskeny oldalhajókról írt, amelyhez oldalról nagy, részben zárt és boltozott karzatlépcső-alapozások és egyéb térelválasztó elemek csatlakoztak. Hangsúlyozta, hogy a mellékhajókat elválasztó oszlopsorok feltúnően masszív alapozásai egyenlőtlen távolságokra vannak. Az apszis mellett eredeti helyükön megtalált oszloplábazatok faragottak. A monostortól északra található, nyolcszög alakú hajóból és a nyolcszög öt oldalával záródó szentélyből álló kápolna építési idejét a 13. század végére, esetleg a 14. századra tette, a templomtól délre lévő kolostornégyszög teljes kiépítését, valamint a templom gótikus átépítését pedig a 14-15. század fordulójára. A monostortemplomot megelőző, az alapítólevélben említett „régi" templom építését - az egyik templom melletti sírban talált Szent István-érem alapján - a Koppány leverése utáni térítéshez kötötte. Ugyanakkor a korábban itt élőkre utaló, 10. századi kerámiát is említett a területen. ${ }^{5}$ A publikációban közölt alaprajz nem teljes. Több, csak alapozási szintben észlelt falmaradvány nincs rajta ábrázolva, a Zádor Mihály által vezetett múemléki helyreállításkor azonban ezeket a falakat is jelölték.

Nagy Emese 1978-ban és 1994-ben ismét írt az épületról. A templom alaprajzát ekkor már a centrális és a hosszanti térelrendezés kombinációjaként jellemezte. A középső négy nagy, szabályos négyszögben elhelyezkedo alapozást „kiemelt középtérhez" kötötte. Megemlítette, hogy az alapítólevélben szereplő régi templom nem rekonstruálható, de nyomai a 11. századi temp-

3 A kolostor történetéről bővebben: ZÁDOR 1964, 28-37, 45-48; GYÖRFFY 1975, 66-67; KOMJÁTHY 1975, 75-76; MAgYAR 1981, 3-8; Hervay 2001, 527; ARADI 2007, Adattár.

4 A Rippl-Rónai Megyei Hatókörú Városi Múzeum (korábban SMMI) adattára, 662-666.

5 NAGY 1973, 335-338. lom alapfalaiban helyenként felfedezhetőek voltak. Úgy vélte, a templom analógiái bizánci területen kereshetők. ${ }^{6}$

Az épületegyüttest elemző tanulmányokban a monostortemplom rekonstrukciója leginkább két jellegzetesség eltérő értelmezésének megfelelően alakult.

Az épület első pillantásra szembetúnő különlegességét az egyenlőtlen távolságokra álló, különbözó pilléralapozások jelentik. Kérdés, hogy a teret három hajóra osztó egységes rendszer részeként lehet-e értelmezni a nyolc alapozást. Nagy Emese két párhuzamos, a templomot három hajóra osztó, négy-négy oszlopból álló sorként értelmezte ezeket, ugyanakkor felhívta a figyelmet különbözőségükre. Négy középső oszlop által kiemelt középtérról írt. ${ }^{7}$ A kétféle alapozást funkcionálisan teljesen elkülönítve is kezelték: így a keleti, szentély előtti palmettás oszloplábazatokat diadalívhez, ${ }^{8}$ a nyugati oszloplábazatokat általában nyugati karzathoz, ${ }^{9}$ máskor narthexhez ${ }^{10}$ kapcsolták. A négy középső pilléralaphoz kapcsolódva többször gondoltak kis középső toronyra ${ }^{11}$ vagy kupolára. ${ }^{2}$ Viszonylag ritkábban merült fel nyugati toronypár lehetósége, ${ }^{13}$ de volt, aki határozottan torony nélküli templomról írt. ${ }^{14}$

$\mathrm{Az}$ épület másik jellegzetességét a templom nyugati részének északi és déli sávjában álló zárt fülkék jelentik, ahová általában oldalsó karzatokat feltételeztek, ${ }^{15}$ de szertartási-előkészületi célra és temetkezési helyül szolgáló mellékhajókként is említették már ezt a területet. ${ }^{16}$

A különbözó értelmezéseknek megfelelőn alakult az épület centrális vagy hosszházas voltának megítélése. Nagy Emese 1973-ban egyszerúen háromhajós épületet említett, de 1978-ban már a centrális és hosszanti elrendezés kombinációjáról írt. Az azóta megjelent publikációkban - bár akadnak a centrális ${ }^{17}$ vagy a hosszanti ${ }^{18}$ jelleget

\footnotetext{
6 NAGY 1978, 91; NAGY 1994, 71-72.

NAGY 1994, 71-72.

8 BuZÁs 2001, 66.

9 Például: Hervay 2001, 527; Tóth 2011, 187-188; ArAdi 2007, 99-101 és Adattár.

10 TÓtH 2001, 242-246; MAgYAR 2012, 4-6.

11 BUZÁs 2001, 66; SZAKÁCS 2009, 39-40.

12 Tóth 2001, 242-46; MAgYar 2012, 4-6.

13 BuZÁs 2001, 66.

14 Hervay 2001, 527.

15 Például: MAROSI 1996, 136; TÓTH 2001, 242-246; BuZÁs 2001, 18; VAlter 2005, 56; Marosi 2013, 111.

16 ZÁdOR 1964, 28-37, 45-48.

17 Tóth Sándor például a négy nagy középső pillér által tartott kupola köré kilencosztatú teret, nyugatra narthexet feltételezett: TóTH 2001, 242-246.

18 Háromhajós, félköríves szentélyú épületről írnak: L. SzABó 1976, 166; ARADI 2007, 99-101 és Adattár; WEHLi 2001, 19.
} 


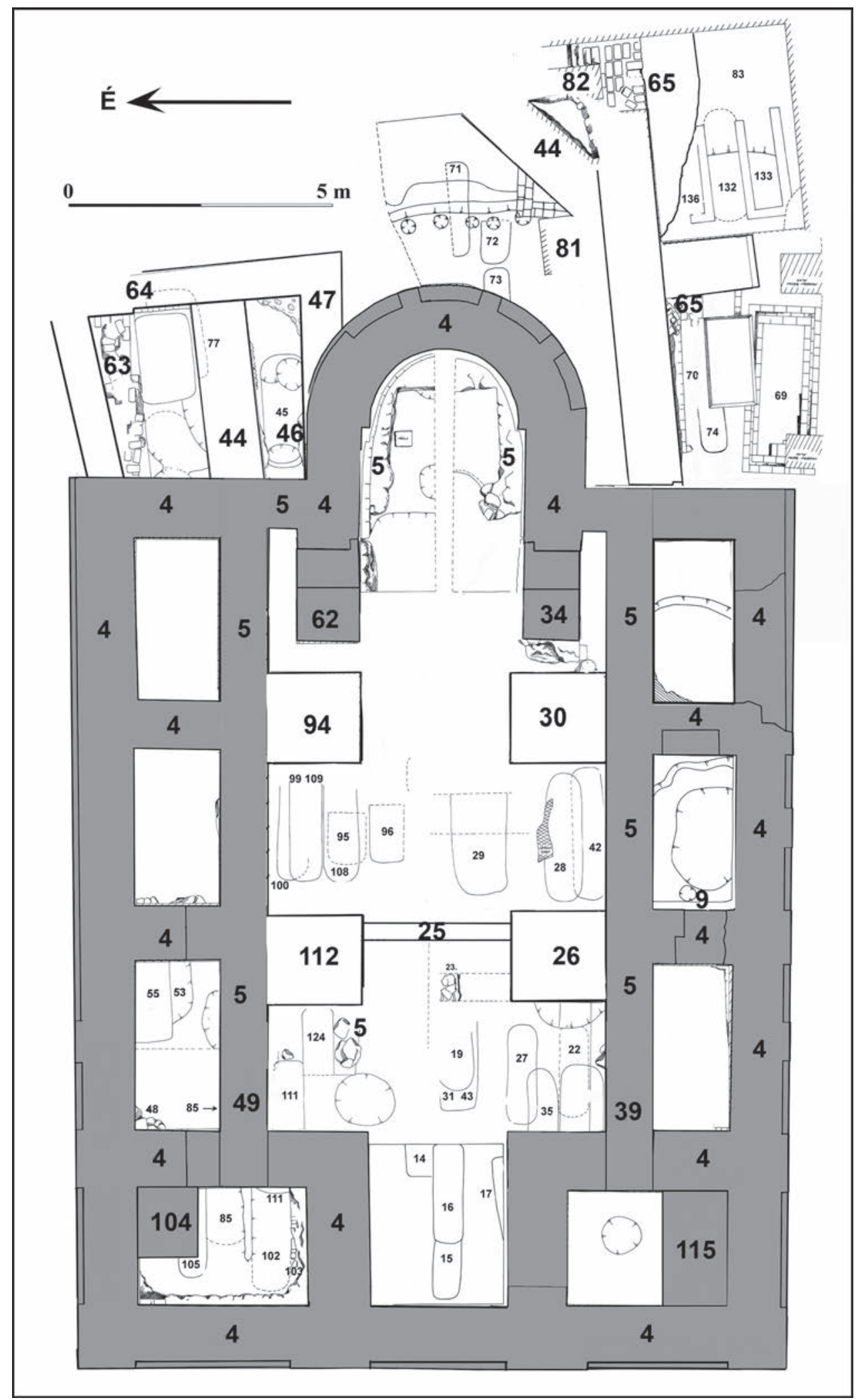

3. kép. Kaposszentjakab. Összesítő térkép a feltárásról (NAGY 1973 alaprajzának felhasználásával) Fig. 3. Kaposszentjakab. Combined plan of the excavations (made using the plan by NAGY 1973) 
hangsúlyozó írások - a leggyakrabban ezek eltérő arányú együtteseként mutatták be az épületet: például centrális térmaggal ellátott hosszanti elrendezésról, ${ }^{19}$ centralizáló részt is tartalmazó hosszanti hajótérről, ${ }^{20}$ centralizáló épületről, ${ }^{21}$ centrális alaprajzra épített bazilikális szerkezetról ${ }^{22}$ írtak. A lehetséges párhuzamokat vizsgálva általában megemlítették, hogy az épület Magyarországon analógia nélküli; utóbb aztán felmerült a hasonló korú szekszárdi és feldebrői templommal való kapcsolata. ${ }^{23} \mathrm{~A}$ távolabbi párhuzamokat kezdetben a bizánci birodalom különböző vidékein keresték. ${ }^{24}$ Késóbb - részben a szekszárdi monostortemplommal való feltételezett kapcsolat miatt - Itália, illetve az Adriai-tenger középső vidékei felé fordult a figyelem. ${ }^{25}$

Az alapítólevélben említett korábbi templomot a kutatás Nagy Emese és Györffy György nyomán ${ }^{26}$ általában a 11. század első évtizedeire, a Szent István-i egyházszervezés időszakára datálja. A ma is álló templomfalakat az 1060-as évekre keltezték, és - kisebb átépítésekkel, átboltozással - egyidősnek gondolták. A kőfaragványok között 12-13. századi darabok is feltúnnek. ${ }^{27}$ Nagyobb, gótikus átalakításra Nagy Emese ásatási megfigyelései szerint a 14-15. században került sor.

\section{A 2013-2014. évi feltárás}

Az elmúlt évtizedekben a helyreállított romterület - elsősorban az apátsági templom és környezete - felújításra és részleges átalakításra szorult. A munka megkezdése előtt feltárásokat folytathattunk a területen. ${ }^{28}$

2013 őszén a feltételezett bejáratok helyén kisebb szelvényt nyitottunk. Ekkor szembesültünk

19 То́тн 2001, 187-188.

20 Marosi 1996, 136.

21 SZAKÁCS 2009, 39-40.

2 BUZÁs 2001, 66.

23 BUZÁs 2001, 66; MAROSI 2013, 111

24 Marosi 1978, 18; MAROSi 1996, 136; NAgy 1994, 72; Tóth 2001, 242-246; VALTER 2005, 56.

25 BuZÁs 2001, 66. Az Adria-vidéki analógiákról a szekszárdi apátság kapcsán: BuZÁs 2010, 262-264.

26 NAGY 1973, 338; GYÖRFFY 1975, 66; ellenkező véleményen volt pl. ZÁDOR 1964, 30.

27 SZIGETVÁRI 1973, 10; TótH 2001, 242-246.

28 A kaposvári Rippl-Rónai Múzeum által folytatott, a cikk szerzője által vezetett feltáráson a múzeum dolgozói közül Nyári Zsolt, Cserép Tamás és Stunya Péter vett részt. A felújítás és az ásatás költségeit a Nemzeti Kulturális Alap és Kaposvár Megyei Jogú Város Önkormányzata fedezte. Köszönettel tartozom Dr. M. Aradi Csilla régésznek, Dr. Mezős Tamás építésznek, valamint L. Balogh Krisztina városi fóépítésznek. A tanulmányban közölt rajzokat Nyári Zsolt készítette. azzal, hogy még a templom területén is jelentős feltáratlan részek maradtak, továbbá, hogy a falszakaszok alatt eltérő szerkezetú alapozások vannak, következésképp a templom falai feltehetően nem mind feltétlenül egykorúak. Ezért a helyreállítás előtt, 2014-ben újra feltártuk a templombelsót, valamint egy a templom szentélyétól délkeletre lévő, kisebb területet (4. kép 1). ${ }^{29}$

Első lépésben eltávolítottuk az újkori visszatöltést. Ebben - mivel az 1960-as években nem használtak fémkeresőt - nagyszámú (főleg római) érmét és kisebb fémleletet találtunk. A viszszatöltés alatt változó mélységben megmaradt, olykor igen vastag középkori rétegek voltak, továbbá összesen 53 (ebbooll a templom területén 38) sír vagy sírrészlet, amelyek közül az 1960-as években többet részleteiben már feltártak. A középkori jelenségek gazdag leletanyagú bronzkori objektumokat vágtak. A római kori megtelepedésre a templom építésénél használt római téglák mellett érmék, kerámiatöredékek utaltak.

\section{A feltárás során megfigyelt és dokumentált alapozások}

A feltáratlan részek kibontása mellett legfontosabb célunk az alapozások szisztematikus dokumentálása és ennek segítségével a különbözó korú falak lehetőség szerinti elkülönítése volt. Az egyes szelvényekben feltárt alapozásszakaszok a dokumentálás során külön számot kaptak. Utóbb, amikor folytatólagosnak és egybetartozónak bizonyultak, egy szám alá kerültek (3. kép, 5-7. kép). A középkori és újkori átépítések miatt a felmenő falak nem mindig egykorúak az alapozásokkal. A falszövetek és a feltárás egyéb eredményeinek részletes leírása azonban meghaladná jelen tanulmány kereteit. Ezért csak azokra a jelenségekre térek ki, amelyek a templom építési periódusaira vonatkozó információkat hordoznak.

Az egyes alapozások számozása megegyezik az alaprajzi jelöléssel (3. kép).

"4": habarccsal leöntött téglákból és kövekből álló vegyes falazat, felső részét ferdén vagy vízszintesen álló téglasor zárja.

Mélysége: 105-140 cm (az alapozások alja 177,23176,92 m tengerszint feletti magasság között volt).

Ilyen alapozáson állt a templom északi és déli fala, az ezekhez kapcsolódó zárt fülkék észak-déli irányú falszakaszai, a templom nyugati fala és a csatlakozó északnyugati, illetve délnyugati téglalap alaprajzú terek (tornyok) falazatai, valamit a jelenleg álló szentély fala is. Az észak-

29 Az összesítő térkép elkészítésekor felhasználtam Nagy Emese 1964. évi dokumentációjának egyik térképét is. 


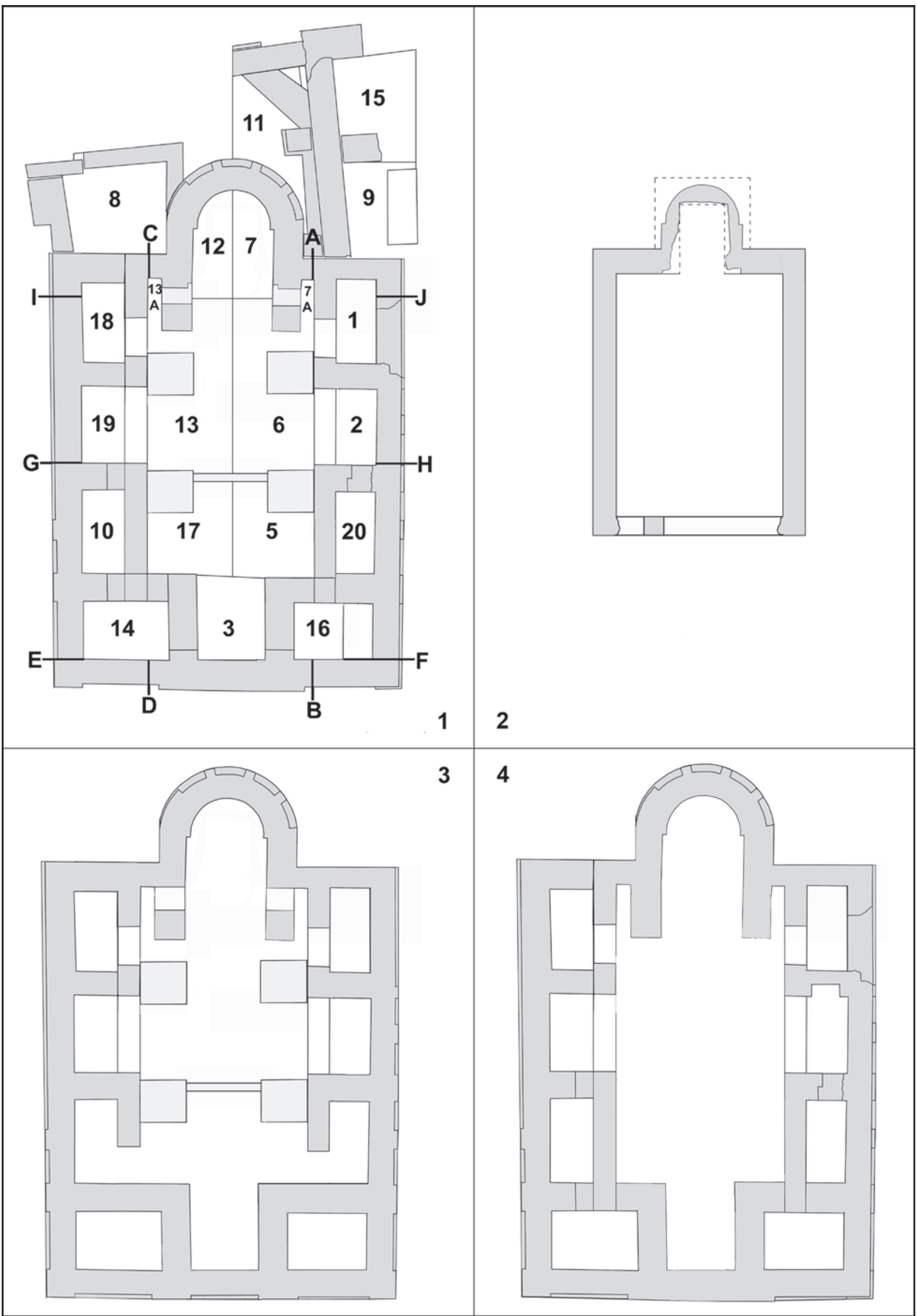


4. kép. Kaposszentjakab. 1: A 2013-2014. évi ásatás szelvényei és a közölt metszetek helye; 2: a korai templom alaprajza; 3: az apátság templomának korai formája; 4: az apátság temploma a kései átépítésekkel

Fig. 4. Kaposszentjakab. 1: Trenches of the 2013-2014 excavation and location of the published sections; 2: Plan of the early church; 3: Early form of the abbey church; 4 : The abbey church with the late rebuildings

nyugati zárt fülke keleti falának északi szakasza metszette az 53. és 55. sírt (9. kép 1). A 17. sírt vágta a délnyugati téglalap alaprajzú tér (torony) északi fala, keleti fala pedig a 22. és 32. sírt rombolta.

"5": két-három sorban, habarcs nélkül vagy minimális habarccsal egymásra tett, 20-60 cm-es megmunkálatlan kövekből és három-négy sorban rájuk falazott, nagyméretú, 40-50 cm hosszú, 8-10 cm vastag téglákból készült alapozás.

Mélysége: 60-80 cm (177,80-177,55 m között).

Ezt az alapozást figyeltük meg a templom belső teréhez csatlakozó déli helyiségsor délkeleti és - kétharmad részben - délnyugati zárt fülkéjének északi fala alatt, valamint - folytatólag - a két helyiség közötti térben; az északi helyiségsor északkeleti és északnyugati fülkéjének déli fala alatt (utóbbi esetben csak a keleti szakaszon), valamint folytatólag - a két helyiség közötti térben (8. kép 1-2). Ezzel a technikával készült, észak-déli irányú alapozástöredék megmaradt a hajó északnyugati harmadának közepe táján, a templom keleti falának szentély melletti szakaszain és - négyzetes alapozás formájában - a jelenleg álló szentélyfalakon belül. A hajó északnyugati harmadában feltárt alapozásmaradványt a 124. sír metszette.

"9": középkori feltöltési rétegen fekvő, habarcsba rakott tégladarabokból álló alapozás.

Mélysége: $70 \mathrm{~cm}(177,58 \mathrm{~m})$.

A délnyugati zárt fülke keleti falán nyitott bejárathoz tartozó alapozás.

"39": habarcsba rakott, kb. 28×8 cm-es, egész téglákból és nagyobb tégladarabokról készült alapfal.

Mélysége: $75 \mathrm{~cm}(177,61 \mathrm{~m})$.

A délnyugati zárt fülke északi falának nyugati szakasza alatt, egy korábbi alapfal („,5”) folytatása nyugat felé. Nyugati végéhez derékszögben csatlakozik a délnyugati, téglalap alaprajzú tér (torony) keleti fala, amelynél szintén késóbbi.

"49": alsó részén habarcsba rakott, kb. $28 \times 8$ cm-es, egész téglákból és nagyobb tégladarabokból, felső felén habarcsba dobált téglatöredékekből készült alapfal.

Mélysége: $80 \mathrm{~cm}$ (177,63 m).

Az északnyugati zárt fülke déli falának nyugati szakasza alatt, egy korábbi alapfal $\left(, 5^{\prime \prime}\right)$ folytatása nyugat felé. Nyugati végéhez derékszögben csatlakozik az északnyugati, téglalap alaprajzú tér (torony) keleti fala, amelynél szintén későbbi. Metszette a 85. sírt (9. kép 2-3).

„115": habarcsba rakott tégladarabokból álló alapozás.

Mélysége: $40 \mathrm{~cm}(177,90 \mathrm{~m})$.

A délnyugati téglalap alaprajzú tér (torony) belsejének déli harmadát elfoglaló lépcsőalapozást egy középkori feltöltésre fektették. ${ }^{30}$

30 A lépcső nyugati fele előtt egy vékony betonsávot találtunk, amely az 1960-as évekbeli dokumentáció alapján egy korábban téglából épült, merőleges irányú lépcsőfokot jelölt.
„104": eredetileg valószínúleg habarcsba rakott tégladarabokból álló alapozás, amely jelenlegi formájában újkori visszaépítés.

Mélysége: $50 \mathrm{~cm}(177,81 \mathrm{~m})$.

Az északnyugati téglalap alaprajzú tér (torony) belsejének északkeleti sarkában feltárt, erősen helyreállított (lépcső?) alapozás alatt kevert középkori réteg és a 105. sír volt.

„34": habarccsal leöntött kő- és tégladarabokból álló alapozás.

Mélysége: $130 \mathrm{~cm}(177,22 \mathrm{~m})$.

A szentély előterében lévő, in situ talált déli oszlop alapozása.

"62": habarccsal leöntött, viszonylag rendezetten behelyezett kő- és tégladarabokból álló alapozás.

Mélysége: $130 \mathrm{~cm}(177,20 \mathrm{~m})$.

A szentély előterében lévő, in situ talált északi oszlop alapozása (9. kép 4). ${ }^{31}$

"26"-,,30"-,,94"-,,112": szabályosan rakott, habarccsal összefogott és leöntött kváderekből készült alapozás.

Mélysége: 186-200 cm (176,70-176,51 m).

A hajóban feltárt nagyméretú pillérek alapozása.

"25": gyenge habarcsba két sor kisebb követ, illetve ezek közé kisebb tégladarabokat tettek.

Mélysége: 16-18 cm (177,96 m), szélessége: 40-44 cm.

Az északnyugati és a délnyugati nagyméretú pilléralapozás között feltárt alapfal. Alatta egy sötét réteget figyeltünk meg, amely alatt bolygatatlan altalaj volt.

"44": agyagba rakott nagyméretú kövekre fektetett, habarccsal kötött téglaalapozás.

Mélysége: 100-110 cm (177,16 m).

A szentély északi oldalán feltárt, általában sekrestyeként meghatározott helyiség közepe táján húzódó, keletnyugati irányú fal, kelet felé túlnyúlik a helyiség keleti falán. Építése során az 54. és 77. sírt bolygatták. A késői időszakban a felmenő falat lebontották, az alapozás a padlószint alá került. Ugyanilyen szerkezetú alapozás északkelet-délnyugati irányú részletét a szentélytól keletre tártuk fel. Utóbbi szakaszt ráásták a 137. árokra és a 80. számú téglasírra, ugyanakkor rombolta a 82. alapfal.

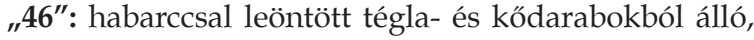
gyenge minőségú alapozás.

Mélysége: $95 \mathrm{~cm}(177,29 \mathrm{~m})$.

A szentély északi oldalán emelt helyiség déli falának nyugati szakaszán megfigyelhető alapozás. Metszette az 59. sírt.

"47": habarccsal kötött kövekből és téglákból készült alapozás.

Mélysége: $160 \mathrm{~cm}(176,29 \mathrm{~m})$.

31 Az eredeti helyükön talált faragott oszloplábazatok alatti alapozáshoz csatlakozik az egykori szentélylépcső helyén kialakított betonsáv. 


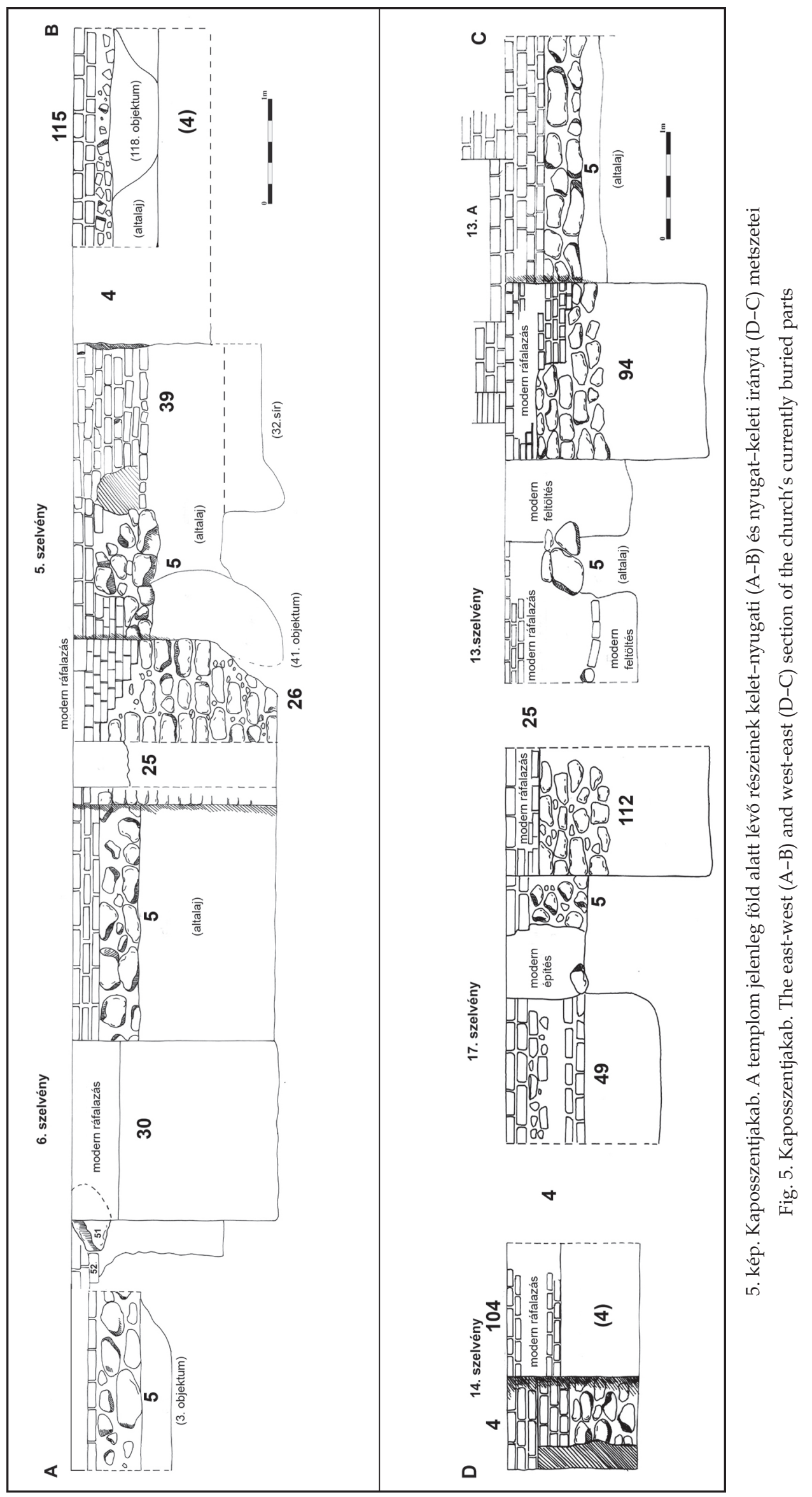




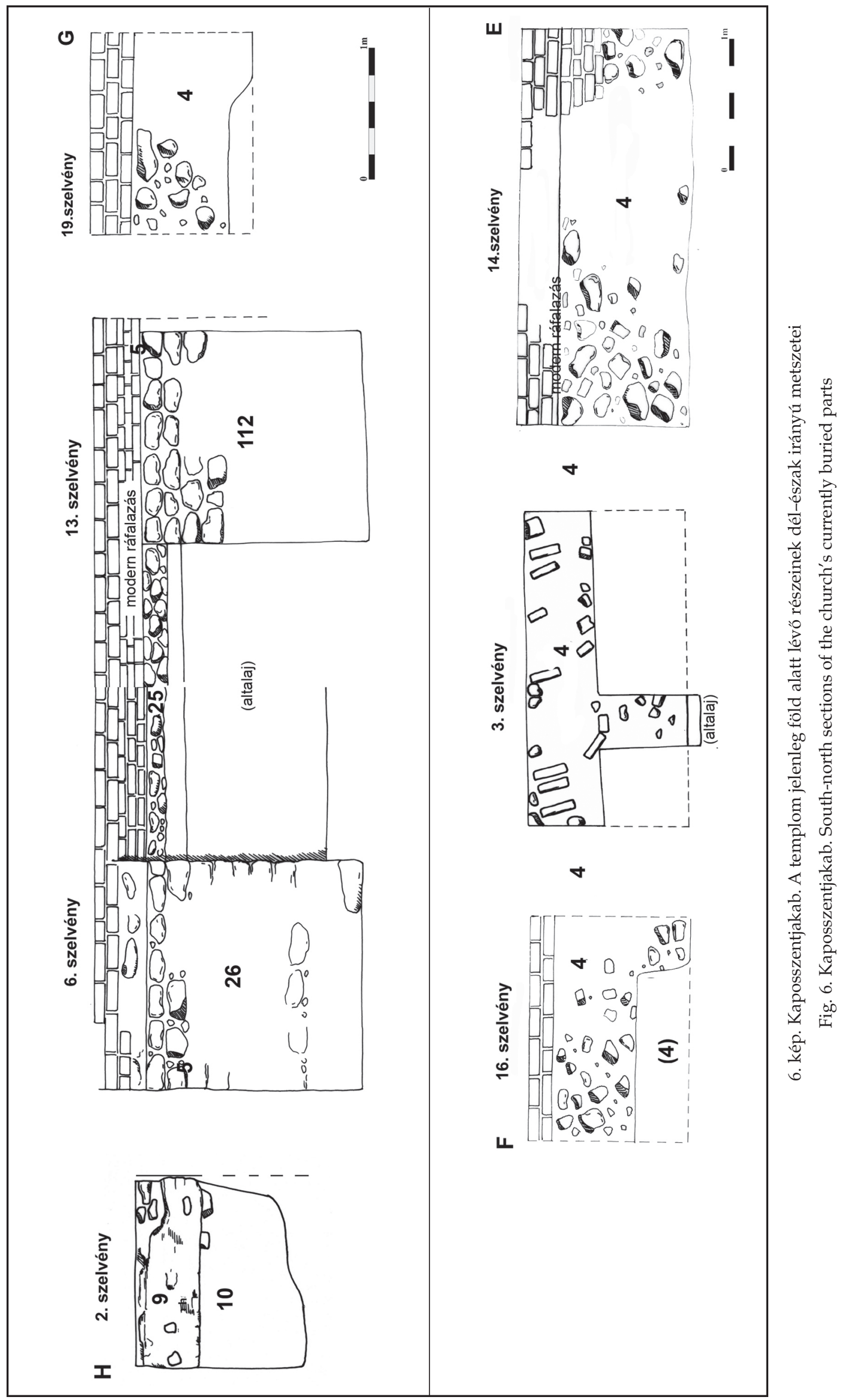




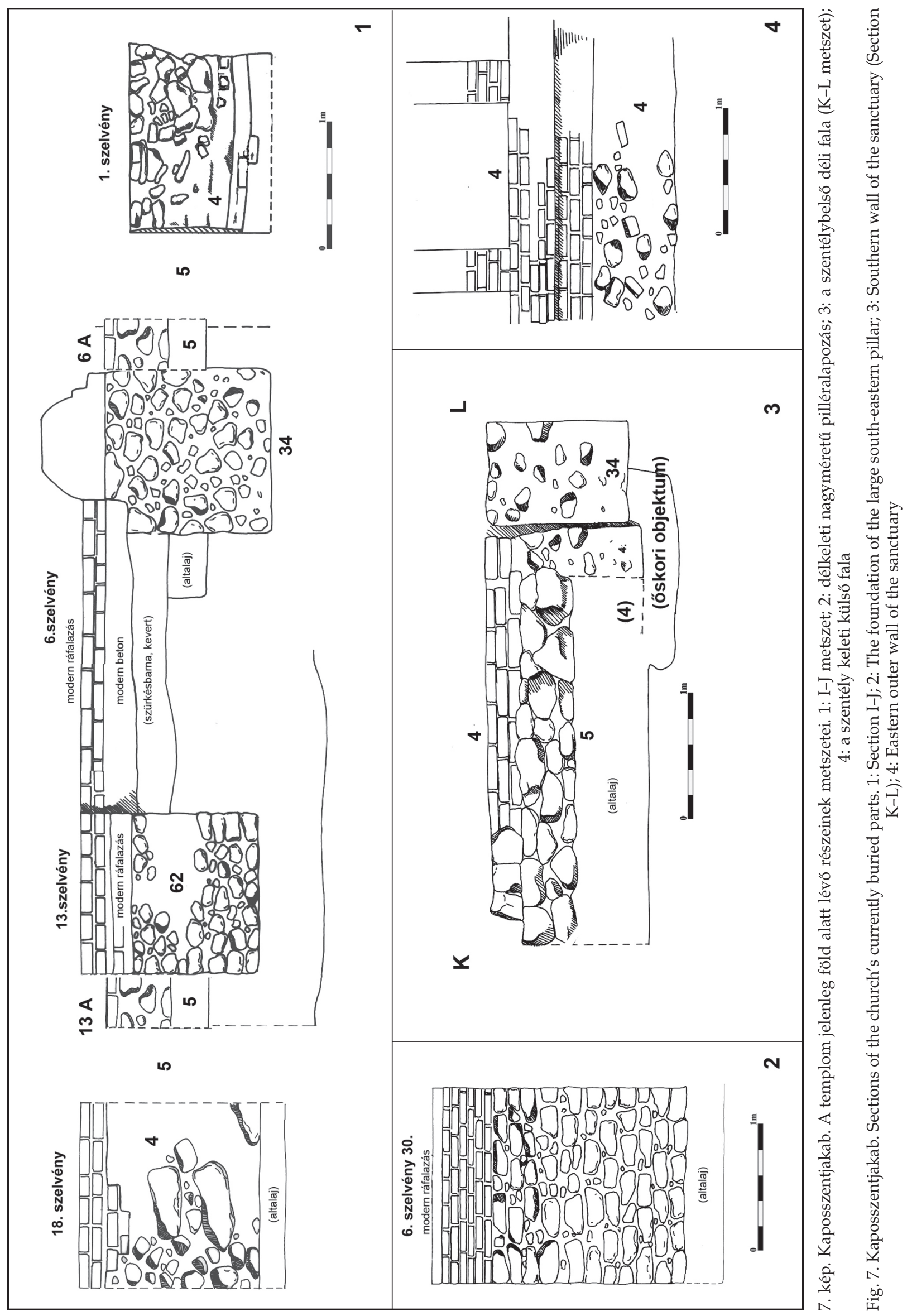


A szentély északi oldalán emelt helyiség déli falának keleti szakaszán, valamint a keleti fal déli szakaszán megfigyelhető alapozás. Itt csatlakozik a helyiség közepén húzódó falhoz.

„64": habarcsba rakott téglasorokból álló alapozás.

Mélysége: $100 \mathrm{~cm}(177,20 \mathrm{~m})$.

A szentélytól északra lévő helyiség keleti falának északi szakaszán megfigyelt alapozás.

"63": agyagba rakott téglákból és tégladarabokból álló alapozás.

Mélysége: $60 \mathrm{~cm}(176,77 \mathrm{~m})$.

Az úgynevezett „,sekrestye” északi falának alapozása. "65": agyagba rakott téglákból és tégladarabokból álló alapozás.

Mélysége: $90 \mathrm{~cm}(176,65 \mathrm{~m})$.

A templom délkeleti részéhez később hozzáépített alapfal, amely a keleti kolostorszárny „pinceként” meghatározott helyiségéig tart. Ráásták a 137. számú árok betöltési (83-84.) rétegeire.

"81": habarcsba fektetett tégladarabokból álló alapozás.

Mélysége: $85 \mathrm{~cm}$ (177,36 m).

A „65” fal középső szakaszához később hozzáépített támpillér alapozása.

„82": habarcsba rakott tégladarabokból álló alapozás, amelyen - az újkori visszaépítés alatt - a 28-30×6-8 cm-es darabokból rakott felmenó fal $38 \mathrm{~cm}$ vastag, öt téglasornyi szakasza is megőrződött.

Mélysége: $68 \mathrm{~cm}(176,86 \mathrm{~m})$.

A templomtól keletre kialakított helyiség nyugati fala. Építésekor rombolták a 65. és 44. alapfalakat; ezekkel együtt a 137. árkot is felülrétegzi.

\section{A korai templom maradványai}

A feltárás folyamán megfigyelt alapfalak közül jól elkülöníthető volt egy sekély, a felszíntől 60-80 cm-re mélyülő alapozás („, $\left.5^{\prime \prime}\right)$. Az alapozási árok alján, 40-45 cm magasságig két-három sorban egymásra tett, 20-60 cm-es, megmunkálatlan kövek feküdtek, amelyek között nem vagy csak minimális mértékben volt habarcs. A kövekre nagyméretú, 40-50 cm hosszú, 8-10 cm vastag téglákból három-négy sort falaztak (8. kép 1-2).32

Úgy vélem, ezeket az alapozásokat az alapítólevélben említett, az apátsági templom alapításakor romosan álló templomhoz kapcsolhatjuk. Ezek bizonyos szakaszaira gondolhatott Nagy Emese, amikor a régi templomot nyomaiban a 11. századi templom alapfalaiban helyenként felfedezhetőnek, de nem rekonstruálhatónak ne-

32 Sajnos több helyen hiányosan maradt meg. A modern helyreállítások előtt ezeket a középkorban is kiegészíthették. vezte. ${ }^{33}$ Ilyen alapozásokat figyeltünk meg a ma romjaiban látható templom belső, $80-85 \mathrm{~cm}$ széles falai alatt, a templom keleti falától az északnyugati és délnyugati zárt helyiségek középső részéig terjedő párhuzamos szakaszon, a templom keleti falának belsó részén, az apszis két oldalán is. Utóbbiak kétségkívül együtt épültek a hosszanti falakkal, azok "fordulnak be". Az apszisban töredékesen, ám jól rekonstruálhatóan került elő a korai épület négyzetes szentélyének alapozása (7. kép 3).34 Azonos szerkezete alapján jól köthető a többi hasonló alaphoz, csupán az új szentély falai választják el azoktól. Az így kirajzolódó templomnak a nyugati fala sérült leginkább. Ez a későbbi templom belsejébe került, így a templombelső temetkezései szinte teljesen megsemmisítették. Megmaradt azonban az egykori északnyugati és délnyugati falforduló indítása, a templom belsejének bontásakor pedig a fal északi szakaszából tártunk fel egy félméteres részletet - gyakorlatilag két nagy követ, amelyek kijelölik az épület egykori nyugati végét.

A templom egyenes szentélyzáródású, nagyjából 12,5 m hosszú, 7,5 m széles egyhajós épület volt (4. kép 2). Felmenő falaiból is azonosíthatóak egyes szakaszok, amelyeket felhasználtak az apátsági templom építésekor. Azonosításukat jellegzetes építőanyaguk teszi lehetővé: az alapozás köveire épülő téglasorok téglái jóval nagyobbak, vastagabbak és világosabb árnyalatúak, mint a később beépítettek. Hasonló téglákat a felmenó falakban csak ezek felett az alapozások felett, elsősorban az egykori templom északi falán találtunk. A folyamatos 20. századi helyreállítások alkalmával a téglák nem mindig az eredeti helyükre kerültek, de így is jól elválik egy-egy ilyen szakasz az északnyugati zárt fülke közepétól keletre, valamint az egykori templom északkeleti részén (8. kép 3).

$\mathrm{Az}$ épület korát a kutatás jelenlegi fázisában egyelóre nehéz lenne pontosan meghatározni. Nagy Emese egy sírban talált Szent István-érme alapján a Koppány leverése utáni egyházszervezés idejére tette alapítását, ${ }^{35}$ Györffy György pedig a pogánylázadásokhoz kötötte pusztulását. ${ }^{36}$ Az alapítólevél mindössze "szerfelett régiségét" és elhanyagoltságát említi, ${ }^{37}$ így elvileg egy korábbi építés sem zárható ki.

33 NAGY 1994, 71.

34 Az 1960-as években is kiásták, bár nem tudták pontosan értelmezni.

35 Nagy 1973, 338.

36 GYÖRFFY 1975, 66

37 Kumorovitz 1964. 


\section{Árok a templomtól keletre}

Egyelöre nagyon keveset tudunk arról, hogy a korai időszakban mi lehetett a templom környezetében. Mindössze egy kis területet vizsgáltunk meg, ahol nem találtunk a legkorábbi időszak épületeire utaló nyomot.

A templomtól keletre egy nagyméretú árok részletét tártuk fel (feltárt szélessége: $188 \mathrm{~cm}$ ) (8. kép 4). Mivel a késői rombolások miatt csak a mai felszíntől 2,5-3 méter mélyen jelentkezett, az 1960-as években nem érték el. Mi is csak 3,5-4 méter mélységig tudtuk követni. Betöltésének felső részét egy visszatemetés rétege alkotta.
Alatta a természetes feltöltődésből őskori és római kerámia, római pénzek, tégladarabok, egy aranyfüggő mellett hullámvonalköteg-díszes kerámia kerültek eló. Az objektumot a feltárt szakaszon falazott téglasírok és későbbi falak metszik.

Az árok belsó oldalán - úgy tŭnik, több sorban - cölöpök sorakoztak. Mi az árok belső oldalán álló sort találtuk meg, de a régi feltárási dokumentáció egyik fotója alapján ettől kb. 80-100 cm-re nyugatra, az egykor lejtősebb domboldalon sekélyebb mélységben egy másik cölöpsor is futott. Az árok feltehetóen a korai templomhoz kapcsolható, valószínúleg nagyobb területet fogott körbe.
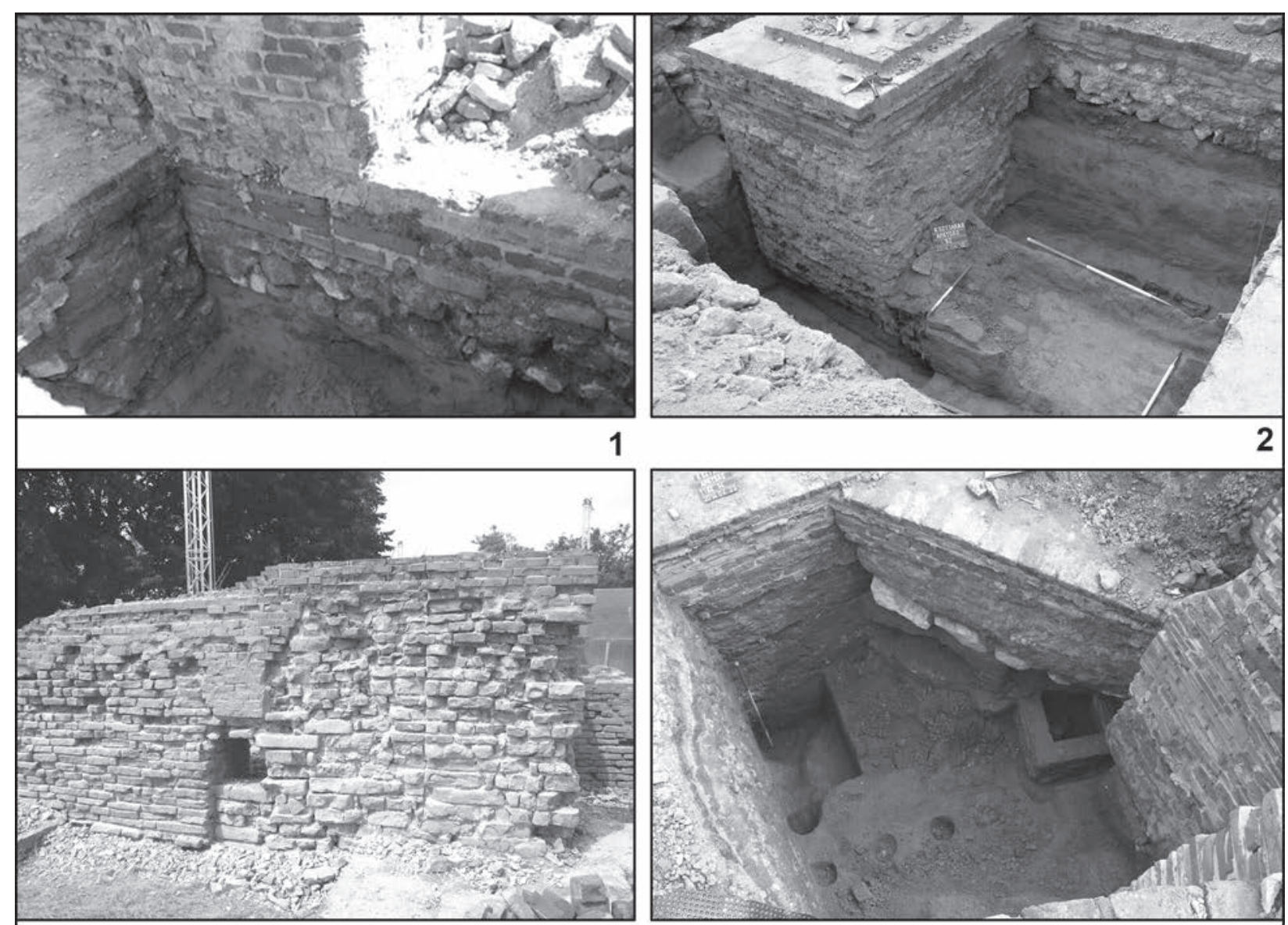

3

8. kép. Kaposszentjakab. 1: A korai templom alapozásának egy szakasza (Stunya Péter felvétele); 2: a korai templomfal és a délkeleti nagyméretú pillér alapozása (Nyári Zsolt felvétele); 3: a korai templom felmenő falának jól elváló maradványai az apátsági templom északi részén (Molnár István felvétele); 4: nagyméretú árok, a belső oldalán lévő cölöpsor részlete és későbbi falmaradványok a templomtól keletre (Molnár István felvétele)

Fig. 8. Kaposszentjakab. 1: Section of the foundation of the early church (photo by Péter Stunya); 2: Foundation of the early church's wall and the large south-eastern pillar (photo by Zsolt Nyáry); 3: Well-distinguishable remnants of the walls of the early church in the northern part of the abbey church (photo by István Molnár); 4: Large ditch with a part of the row of posts and later wall remains east of the church (photo by István Molnár) 


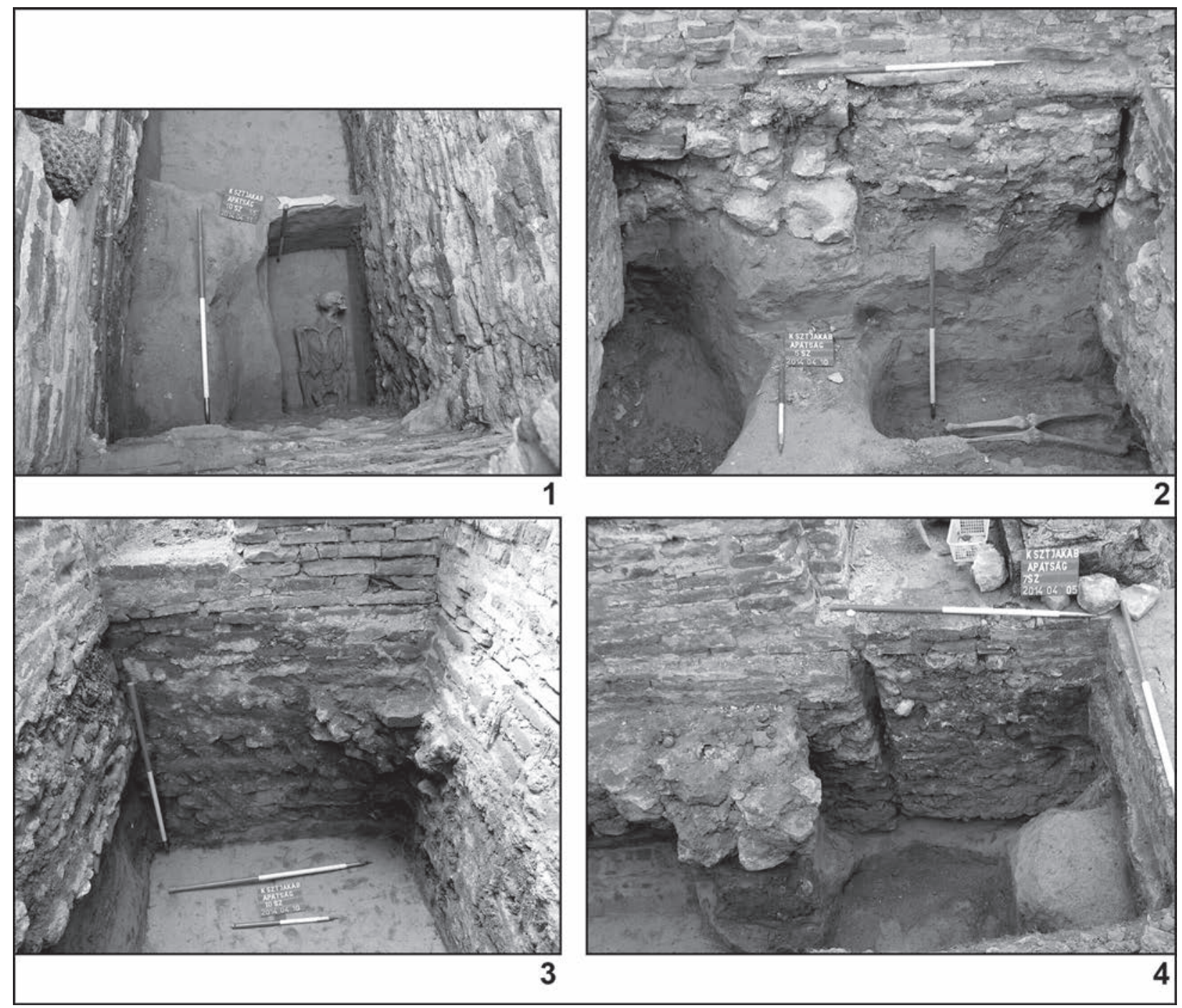

9. kép. Kaposszentjakab. 1: Az apátsági templom falai által metszett sír (Stunya Péter felvétele); 2: három korszak találkozása: a kép bal szélén a korai templom egykori délnyugati sarka, jobb oldalon a monostortemplom tornyának alapozása metsz egy korai sírt, középen a legfiatalabb alapozás (Molnár István felvétele); 3: a monostortemplom korai falai, délre későbbi átépítéshez kapcsolható alapfal (Nyári Zsolt felvétele); 4: a déli faragott oszloplábazat alatti alapozás, mellette a szentélyfal és a korai templom apszisának alapozása (Molnár István felvétele)

Fig. 9. Kaposszentjakab. 1: The grave cut by the wall of the abbey church (photo by Péter Stunya); 2: "Intersection" of three periods: the south-eastern corner of the early church on the left, an early grave cut by the foundation of the abbey church's tower on the right, and the latest foundation in the middle (photo by István Molnár); 3: Early walls of the abbey church with a younger foundation to the south; (photo by Zsolt Nyáry); 4: Foundation under the carred base of the southern next to the chancel of the abbey church and of the old church (photo by István Molnár)

\section{Az apátsági templom korai formája}

Az alapozások és a falmaradványok jó részét az apátsági templomhoz köthetjük (4. kép 3). A 98$110 \mathrm{~cm}$ széles falak alapozásai kb. 100-140 cm mélységúek voltak. A kiásott alapárkot téglákkal és kövekkel töltötték meg, majd habarccsal öntötték le. Az alapozást végül a lábazatnál három fekvő vagy egy ferdén álló téglasorral zárták le („,4”) (9. kép 3). Úgy túnik, az előzó épület alapjának köveit is felhasználták. Ilyeneket találunk nagyjából mindenhol a templom külső falainál, és az ezekből induló, észak-déli irányú kis falak is így vannak alapozva. Habarcsozásuk folytatólagos, láthatóan egyszerre készültek, tehát a templom két oldalán sorakozó, félig zárt terek ha nem is mai formájukban - egyidősek a külső határoló falakkal. Az egyes épületrészek sarkait megerősítették, az alapok itt rendszerint kissé kiívelődnek. A nyugati oldalon a hasonló alapozások két toronyszerú téglalapot rajzolnak ki, amelyek nem jelennek meg Nagy Emese beszámoló- 
jának térképén. ${ }^{38}$ A nyugati oszloplábazatok ezek belső sarkain állnak: az északi megmaradt eredeti helyzetben, a délit azonban az 1960-as években nem itt találták, csupán az alapot képező nagy kő volt az eredeti helyén. A felsorolt falszakaszok folytatólagosak. Egyszerre, a régi templom alapjaihoz épültek, annál egyértelmúen későbbiek. Keleten a szentély a régi falakhoz csatlakozik, azokat részben rombolja is. Nem kapcsolódik közvetlenül a többi, vele egykorú falhoz, de itt is ugyanazt az alapozást találjuk.

Nagyon hasonló szerkezetú, 120-130×160-80 cm nagyságú alapozás van a szentély előtt lévő faragott oszloplábazatok alatt (,34", ,62") (9. kép 4). Közöttük és a szentélyfal alapozása között csak egy kis rés van. Utóbbinál némileg sekélyebbek és talán valamivel szabályosabban rakottak is, de alapozásuk alapvetően azonos, az apró eltérések talán az építés folyamatával magyarázhatók. A faragott oszloplábazatok így az alattuk lévő alapozások mellett a fentebb bemutatott falakat is keltezhetik.

A felmenő falak külső síkját lizénák tagolták. Nagyrészt igazodnak a templom belső szerkezetéhez. A nyugati sarkokon erósebbek, megerősítésnek hatnak, a nyugati fal közepén a bejáratot jelölik ki. A szentély falának keleti-délkeleti szakaszán jelenleg csupán három látható (7. kép 4). $\mathrm{Az}$ északi templomfal keleti része csak hiányosan maradt meg, de a korábbi ásatási felvételeken látszik egy kiomlott faldarab, rajta egy falsáv nyomával, amelynek délkeleti párja az itt kialakított bejárat miatt nem maradhatott meg. A lizénák eredetileg nyilván szimmetrikusan kiosztva tagolták a templom hosszfalait: a sarkokon és a befelé tartó, rövid falak meghosszabbításában szélesebb, az ezek által kijelölt szakaszok közepén keskenyebb falsávokat alakítottak ki.

Egy elfalazott bejárat nyoma maradt meg a templom déli falának közepén. A külső oldalon egy lizéna takarja a szélét. Kérdéses, hogy ez ténylegesen múködött-e, illetve hogy a templom délkeleti részén mikor nyitottak bejáratot.

A templom közepén lévő, egyfajta középteret kijelölő, egymástól 230-250 cm-re lévő, 170×160 cm kiterjedésú nagy pilléralapok közel 2 méter mélyek (,26", , ,30", ,"94", , 112"). Alapozásuk igen jó minőségú: szabályosan rakott, habarccsal összefogott és leöntött kváderekből áll. Amennyire a habarcsréteg alatt megfigyelhetó, többfajta követ, például lilásvörös homokkövet és sárgásfehér mészkövet is használtak. A kövek közti réseket apró téglatörmelékkel tömték be. Az általunk feltárt részen régészeti jelenséget nem vágtak.
Szorosan a korai templom falai mellé épültek, de azoktól jellegükben nagyon eltérnek. A régi templom falai mellettük maradtak meg a 20. századra. Az apátsági templom belső, észak-déli irányú falai is ezekhez csatlakoztak. Tehát ha esetleg nem is utóbbiakkal együtt épültek, mindenképpen figyelembe vették és felhasználták ezeket. A nagy pilléralapozások és a szentély előtti oszloplábazatok alapozásának oldalán is ívelt domborulatok maradtak meg, talán az egykori zsaluzat nyomai. A hasonlóság miatt - talán eltérő szerkezetük mellett is - egyszerre építettnek tekinthetjük ezeket.

A nyugatabbra lévő pilléralapok között sekély alapozás fut, amely alig 16-18 cm mélyen maradt meg. 40-44 cm széles, talán a kórusrekesztő helyét jelöli $\left(, 255^{\prime \prime}\right)$. Elég gyenge habarcsba két sor kisebb követ, illetve ezek közé kisebb tégladarabokat tettek. A pillérekhez hasonlóan később visszabontották, a most felül lévő rész 20. századi visszaépítés. A nagy pilléreknél nem korábbi, ugyanakkor alatta - egy talán tereprendezéshez kapcsolható feketés réteg alatt - a sárga altalajt találtuk meg. Korai sírokat nem metszett, a későbbiek hozzá igazodtak. Építését mindez az apátsági templom korai korszakára valószínúsíti. Ilyen eredetúnek kell tartanunk - az alattuk lévő bolygatatlan talaj alapján - a nagy pilléralapozásokat is (7. kép 2). (Egyúttal megállapítható, hogy a korábbi templom hajójába valószínúleg nem temetkeztek.)

A késő középkori átépítés miatt a szentély előterének korai formájáról keveset tudunk. Az oszlopalapok feltehetően diadalívet tartottak. A korábbi feltárás során egy bordázott felületú, csavart oszlop töredékét találták meg a déli oszlopláb felett, azzal együtt elfalazva. ${ }^{39}$ A lábazatok lecsapott sarkai talán korai rekesztőkorláthoz kapcsolhatók.

A 18,5×12,5 méteres apátsági templom építéséhez felhasználták a korábbi templom maradványait. Az épületnek feltehetóen nyugati toronypárja és keleti félköríves apszisa volt. A középső részen egy keresztirányú, egybefüggő tér nyílt a négy nagy pillér között, amelyek kupolát vagy kis tornyot tarthattak. A nyugatiak között kórusrekesztó lehetett, a szentély előtt diadalív, közte rekesztőkorlát állhatott. A templombelső négy sarkában egy-egy félig zárt tér volt. Bejáratuk a templombelső felé esô falak nyugati részén nyílt, felettük karzat lehetett.

$\mathrm{Az}$ épület eredeti formájának rekonstruálása továbbra is nehéz feladat. A templom képét döntóen meghatározhatta a keresztirányú középső tér magassága, ha az mintegy kereszthajósze- 
rúen, egységesen kiemelkedett, és a templom közepével megegyező, a saroktereknél nagyobb magassággal bírt, centrálisabb képet adott a templom középső részének. Ha azonban északon és délen alacsonyabb, a sarkokkal egyező magasságú volt, úgy tömbje egyértelmúen hosszanti elrendezésre utalt. A templom különleges szerkezetének egyik magyarázata a korábbi templom felhasználása lehet. Ez tervszerúen történt: az új templom szinte körbeölelte a régit, amelynek védőszentjét is átvette.

\section{Az Árpád-kori monostor épületei}

A szentélytől délkeletre folytatott kutatás során agyagba rakott téglákból álló, széles alapozásmaradványt tártunk fel („,65”), amely két téglasírt is bolygatott. A hozzá tartozó felmenő falnak már csak egy kisebb, nyugati szakasza áll. Az alapfal részleteit az 1960-as években megtalálták, de mivel nem tárták fel teljes mélységig a területet - nem tudták azonosítani a kései síroktól, beásásoktól rombolt alapozás eredeti kiterjedését, funkcióját. A rétegviszonyok alapján bizonyos, hogy eredetileg egy a templomhoz feltehetően még az Árpád-korban hozzátoldott épület alapozásához tartozik, amely keleten a domb aljától induló, Nagy Emese által - valószínúleg tévesen - pinceként meghatározott, boltozatos helyiséghez csatlakozik. Jól érzékelhetően annak faláig tart. Egy épületsort alkothattak, déli fala valahol a mostani kerengő északi szárnyának déli falánál lehetett. A 14-15. század fordulóján kiépülő gótikus kolostornál korábbi épületról van szó, hiszen legkésőbb ez utóbbi megépülésekor jórészt már el kellett bontani. Feltételezhetjük, hogy a "pince” is hasonló korú. Ez indokolná, miért "ugrik ki” a fala a kerengó vonalából. A fal elbontása után több temetkezés is rombolta az alapozás maradványait. Úgy vélem, ha nem is a legkorábbi, de még az Árpád-korban kiépülő, a templomhoz képest kissé elfordított, délnyugatra tájolt helyzetú kolostorszárny nyomát találtuk meg.

\section{A templom késóbbi átépítésének nyomai}

$\mathrm{Az}$ 1060-as években épült monostortemplomot később átalakították, újabb falszakaszokat építve (4. kép 4). A tornyok és az eredetileg a korábbi templomhoz kapcsolható, sekélyebben alapozott belső falak között azokkal kötésben nem lévő, egyértelmúen késóbbi alapozások vannak („,39”, "49"). Ezek az alapozások 70-80 cm mélyek, és habarcsba rakott téglákból állnak, de az északi ol- dalon lévő alap $\left({ }^{\prime}, 49^{\prime \prime}\right)$ felső része töredékes téglából épült (9. kép 3). Tehát csak későn alakultak ki a templom nyugati felének északi és déli falánál lévő zárt fülkék, a tornyok pedig eredetileg nem kapcsolódtak a tőlük keletre lévő belső falakhoz. Ezeket később húzták el a tornyokig, azokba bekötve, az épületrészt átalakítva. A falakon látszik is itt egy elválás. Elképzelhető, hogy az átalakítás a boltozáshoz kapcsolódik - fóként, ha az a belső falakra, a karzatokra támaszkodott. Számos egyéb kérdés mellett ennek megválaszolásában is a kőanyag feldolgozása segíthet. Nagy Emese véleménye szerint a templom gótikus boltozata a ma látható kolostorépületekkel egy időben, a 14-15. század fordulóján készülhetett, így a zárt fülkék kialakítását is erre az időszakra tehetjük.

Legkésóbb ekkor meg kellett nyitni az így kialakuló nyugati fülkék keleti, rövid oldalán lévő bejáratokat. Ez természetesen korábban is megtörténhetett, de a déli fülke keleti fala előtt lévő, habarcsba rakott téglasorokból álló, az említett falszakaszok alattihoz hasonló szerkezetú és mélységú alapozásszélesítés $($ „,9") alapján inkább egy időre tehetjük a két munkálatot. Továbbra is kérdéses, mikor és milyen céllal alakították ki az északnyugati fülke külső falán lévő, a helyreállításkor erósen visszaépített, a templom tengelyével párhuzamos boltozást, amelynek délnyugati párja nem készült el.

A korábbi kutatás során a szentély előtt, a faragott oszloplábak között lépcső maradványát találták meg, amely alatt megfigyelhető volt a szentély eredeti szintje is. Ez alapján a szentély megemelése és a lépcső kialakítása egy későbbi időszakban, Nagy Emese megfigyelései szerint a gótikus átépítéshez kapcsolódóan történhetett. Az alsó lépcső helyét jelzi ugyan helyreállítás, de ma már sajnos beton van helyette, amelyre téglasorokat fektettek. A szentély előtti faragott oszloplábazatokat - ahogyan a nyugatiakat is - ekkor elfedték. A szentély falait nyugat felé meghosszabbították, ráhúzták az oszlop alapozására. A nagy pilléreket eltüntették, alapozásukat is visszabontották. Jelenleg erős újkori visszaépítés miatt érik el a felszínt. Ezek tehát nagy valószínúséggel nem álltak már, amikor az északi és déli zárt fülkék elnyerték jelenlegi formájukat. Az 1960-as években még érzékeltek egy késő középkorra keltezett padlót, amely az akkor készült fotókon jól láthatóan a visszabontott pillérek szintjén volt. ${ }^{40}$ Úgy vélem, mi is ennek a szárazon rakott padlónak a maradványát találtuk meg egy kis, 30 cm-es szakaszon, a környezetében lévő

40 Minderről részletesebben: MoLNÁR 2014, 189-192. 
felmenő falak indulásának szintjénél (178,35178,28 m) 20-25 cm-rel mélyebben, 178,08 m tengerszint feletti magasságon. A nyugati rekesztőkorlát alapozása szintén visszabontásra került, gyakorlatilag alig maradt belőle valami.

A ma a templom nyugati végén látható, feltehetően a karzatokra vezető lépcsőalapok közül a délnyugati (,115”) maradt meg viszonylag jó állapotban. Az északnyugati („104”) jórészt 20. századi visszaépítés. A 11. századi falakhoz épültek, de egyelőre nem állapítható meg, hogy mikor történt mindez.

Ezek alapján a templom késői korszakában „hagyományos", hosszanti elrendezésú, gótikus stílusban beboltozott épület lehetett. A belsejében álló pillérek és az általuk tartott kupola vagy torony ekkor már elbontásra kerültek, a padlót lesüllyesztették, a szentélyt megemelték, elé lépcsőt alakítottak ki. A kolostori épületekkel a délkeleti részén nyíló bejárat kötötte össze, a nyugati bejárat is megmaradt.

A múemléki helyreállítás szintén jelez három falszakaszt (,44"), amelyek valószínúleg egy megkezdett, de végül nem megépített poligonális szentély nyomai. Mivel a korábbi szentély falai viszonylag magasan állnak, bizonyos, hogy az építók hamar meggondolták magukat. Mi a templom mai szentélyétől északra kialakított helyiség közepén futó északi és délkeleti alapfalat tártuk fel. Ezek alapján is egyértelmú, hogy nemcsak a 11. századi épületnél későbbi, hanem az ahhoz délkeletról csatlakozó, már említett, Árpád-korra valószínúsített épületet is rombolja. Ugyanakkor nem is a legkésóbbi időszak terméke, hiszen mindkét szakaszon falak („,64", „,82") metszik maradványait. Nagy Emese dokumentációja alapján a délkeleti falat megtalálásakor 15. századi járószint fedte. A templomhoz kissé eltérően, délnyugatabbra tájolt szentély alapozásának szerkezete egyedi, csak ezekre a falakra jellemzó. A nagyjából 100-110 cm mély alapárok aljára hatalmas, 15-30×40-60 cm-es, a templomban máshol nem használt, szürke színú köveket fektettek az agyagba. Erre 40-50 cm magasságú, falazott alapozás következik, amelyen délkeleten a keskenyebb, felmenő falból is megmaradt két téglasor (8. kép 4). Eredetileg talán magasabban is megépült, de mindenképpen visszabontották, hogy a falcsonk ne lógjon ki. Jelenleg több téglasoros újkori visszaépítéssel éri el a felszínt. Támpillér nyomát nem találtuk. Eltéró szerkezete, illetve a ráépülő későbbi falak miatt nem kapcsolnám össze a templom beboltozása és a kolostornégyszög kiépítése közben végzett munkákkal. Feltehetóen egy korábban megkezdett átalakítás maradványa.
A szentélytől északra egy helyiség látható, amely jelenlegi formájában a 14-15. század előtt nem alakulhatott ki. A templomhoz képest, a környező kolostorépületekhez hasonlóan ferdén tájolt keleti fala ráépült az említett poligonális szentélyre.

\section{Temetkezések}

A dombra az apátsági templom építése előtt is temetkeztek, hiszen ennek falai többször metszenek sírokat (9. kép 1-2). 2013-2014-ben több ilyen, olykor egymást is felülrétegző temetkezést tártunk fel a régi templomtól északra és nyugatra. Nagy Emese dokumentációjában további példákat találunk az elsó épülettől délre is. A régi templom falai alatt nem, de azokhoz közel, akár fél méterre is kerültek elő sírok. Az alapítólevél szerint 1061-ben laktak az akkor már elhanyagolt, pusztán álló templom mellett. Feltételezhetjük, hogy a temetkezések a templom részleges pusztulása után is folytatódtak. A korai sírok jó része sajnos összekeveredett a későbbiekkel; azok és az építkezések bolygatták, megsemmisítették őket, így leginkább a monostortemplom falai által romboltakat köthetjük egyértelmúen a korai időszakhoz.

Feltehetően az apátsági templom építése utáni időszakra keltezhetünk több falazott téglasírt. Ezeket mélyre ásták, sorokat alkottak. Az általunk feltárt részen a korai templomhoz kapcsolható árkot metszik, egyébként minden fiatalabb náluk.

A templomba évszázadokig temetkeztek. Sírok és sírtöredékek a templom teljes területén, a templombelsőben a déli és az északi, félig zárt területeken, "fülkékben" is napvilágra kerültek. A szentélyt az 1960-as években jelentősen átforgatták, csak egy vékony feltáratlan sáv maradt. Ennek alján egy négyzetes, $30 \times 34 \mathrm{~cm}$-es, lapos tégladarabot találtunk eredeti helyén. Elképzelhető, hogy egy egykori sír maradványa. Mellette ívelt beásás van a sárga altalajban, amely az apátsági templom falának vonalát $50 \mathrm{~cm}$-rel beljebb követi. Akár ez is rombolhatta a korai templom maradványait.

A templom ma látható, magasabban álló falai legalább három építési periódus nyomait őrzik. Nem csak az alapítás előtt itt álló épület maradványainak felhasználása, de a későbbi átalakítások is jelentősen módosították formáját. A kolostor területén nyitott kis szelvényben feltárt, egymást többszörösen metsző falszakaszok a kolostorépületek többszöri átépítéséról tanúskodnak. A pontos periodizációt a részletes feldolgozás és a remélt további feltárások segíthetik. 


\section{IRODALOM}

M. ARAdi CSILla

2007 Somogy megye Árpád-kori és középkori egyházszervezetének létrejötte és megszilárdulása. Doktori disszertáció. http://doktori.btk.elte.hu/hist/aradi/disszert.pdf

\section{BUZÁS GERGELY}

2001 Az államalapítástól a tatárjárásig. In: Buzás Gergely-Tóth Endre: Magyar építészet. A rómaiaktól a román korig. Budapest.

2010 A szekszárdi apátság temploma a középkorban. In: Kollár T. (szerk.): Építészet a középkori Dél-

GYÖRFFY GYÖRGY Magyarországon. Budapest, 555-603.

1975 Kaposvár az Árpád-korban. In: Kanyar J. (szerk.): Kaposvár. Várostörténeti tanulmányok. Kaposvár, 63-73.

HeRvay F. LEVENTE

2001 Bencések és apátságaik a középkori Magyarországon. In: Takács I. (szerk.): Paradisum plantavit. Bencés monostorok a középkori Magyarországon. Kiállítási katalógus. Bencés Főapátság, Pannonhalma, 461-567.

Komjáthy MiKLós

1975 A középkor végi Kaposvár. In: Kanyar J. (szerk.): Kaposvár. Várostörténeti tanulmányok. Kaposvár, 75-92.

KumOROVITZ L. BERNÁtH

1964 A zselicszentjakabi alapítólevél 1061-ból (Die Stiftungsurkunde von Zselicszentjakab aus dem Jahre

MAGYAR KÁLMÁN 1061. Die früheste Erwähnung von „Pest“). Tanulmányok Budapest Múltjából (Budapest) 16, 43-83.

1981 Kaposszentjakab. Bencés apátság romjai. Tájak, Korok, Múzeumok Kiskönyvtára 68. Budapest, 1981.

2012 A bencés rend középkori somogyi egyházai nyomában 2. Somogyi honismeret. Kaposvár, 1-2.

MAROSI ERNÓ

1978 Árpád-kori kőfaragványok - Árpád-kori építészeti fejlođdés. In: Tóth M.-Marosi E. (szerk.): Árpád-kori kőfaragványok. Székesfehérvár. A Székesfehérvári István Király Múzeum Közleményei D sorozat 121. Székesfehérvár, 15-28.

1996 Bencés építészet az Árpád-kori Magyarországon. A rendi építőiskolák problémája. In: Takács I. (szerk.): Mons Sacer 996-1996. Pannonhalma 1000 éve I. Pannonhalma, 130-142.

2013 Romanika Magyarországon. Budapest.

MOLNÁR ISTVÁN

2014 Újabb kutatás a kaposszentjakabi apátság területén 1. (Research in the area of the Benedictine abbey,

NAGY EMESE

Kaposszentjakab. Part 1). Rippl-Rónai Múzeum Közleményei (Kaposvár) 3, 185-198.

1973 Előzetes jelentés a kaposszentjakabi ásatásról (Rapport préliminaire sur les fouilles de l'abbaye de Kaposszentjakab). Somogyi Múzeumok Közleményei (Kaposvár) 1, 335-339.

1978 Kaposszentjakab. In: Tóth M.-Marosi E. (szerk.): Árpád-kori kőfaragványok. Székesfehérvár. A Székesfehérvári István Király Múzeum Közleményei D sorozat 121. Székesfehérvár, 91-92.

1994 Zselicszentjakab. In: Mikó Á.-Takács I. (szerk.): Pannonia regia. Múvészet a Dunántúlon. Budapest, 71-72. L. SZABÓ TÜNDE

1976 A kaposszentjakabi bencés apátság múemléki helyreállítása. Múemlékvédelem (Budapest) 1976/3, $165-168$.

SZAKÁCS BÉLA ZSOLT

2009 Román kori múvészet. In: Bellák G.-Jernyei Kiss J.-Keserú K.-Mikó Á.-Szakács B. Zs.: Magyar múvészet. A múvészet története 16. Budapest, 24-43.

SZIGETVÁRI GYÖRGY

1973 Építészeti emlékek Somogyban. Kaposvár.

TÓTH SÁNDOR

2001 Zselicszentjakab. In: Takács I. (szerk.): Paradisum plantavit. Bencés monostorok a középkori Magyarországon. Kiállítási katalógus. Bencés Főapátság, Pannonhalma, 342-346.

2011 Szerzetesi templomok. In: Kőszeghy P. (főszerk.): Magyar múvelődéstörténeti lexikon. XI. Középkor és kora újkor. Budapest, 186-199.

VALTER ILONA

2005 Árpád-kori téglatemplomok a Nyugat-Dunántúlon. METEM Könyvek 43. Budapest.

WEHLI TÜNDE

2001 Múvészet a honfoglalástól 1241-ig. In: Galavics G.-Marosi E.-Mikó Á.-Wehli T.: Magyar múvészet

ZÁDOR MIHÁLY

a kezdetektől 1800-ig. Budapest, 9-91.

1964 Kaposvár. Budapest. 


\section{NEW INVESTIGATIONS IN THE ABBEY CHURCH OF KAPOSSZENTJAKAB}

\section{ISTVÁN MOLNÁR}

The Benedictine abbey of Kaposszentjakab (Zselicszentjakab) was founded in 1061 and consecrated in 1067. Although the excavations conducted between 1960 and 1966 enabled the reconstruction of the church's ground plan, large areas of the abbey remained uninvestigated. The new excavations in 2013-2014 focused on the abbey's church and the area to its south-east. The excavation and documentation of foundations dating from various periods enabled the more precise determination of different building periods and the identification of the "old church" that stood in the abbey's area in 1061, mentioned in the abbey's foundation charter. The single-nave, $12.5 \mathrm{~m}$ by $7.5 \mathrm{~m}$ large building had stone foundations. Smaller sections of its brick wall were incorporated into the later abbey church. The church measured $18.5 \mathrm{~m}$ by $12.5 \mathrm{~m}$ with a pair of towers on the western side and a semicircular apse on the eastern side. The four pillars with a massive foundation in the centre probably supported a cupola or a tower. Areas separate from the interior with galleries were created in the corners. New walls were added later, probably during the Gothic rebuilding. The niches in the church's northern and south-western part probably received their final form during this period. 